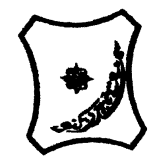

Bayero Journal of Pure and Applied Sciences, 10(2): 300 - 304

Received: November, 2017

Accepted: December, 2017

ISSN $2006-6996$

\title{
SUBSURFACE MAPPING OF GROUNDWATER CONTAMINATION PATHWAY USING GEOELECTRIC METHOD AT WASTE SITE OF KUBANNI BASIN, ZARIA, KADUNA STATE, NIGERIA
}

\author{
Umar, M., ${ }^{1}{ }^{1}$ Bala, B., ${ }^{1}$ Garba, M. A. ${ }^{2}$ and Muhammed, M. A. ${ }^{3}$ \\ ${ }^{1}$ Department of Physics Ahmadu Bello University, Zaria \\ ${ }^{2}$ Shehu Idris College of Health Science and Technology, Makarfi, Kaduna State \\ ${ }^{3}$ Department of Physics, Federal University lafiya, Nigeria \\ *Correspondence author: umardk06@yahoo.com; +2348036865363
}

\begin{abstract}
Electrical resistivity Survey was carried out at Kubanni waste dumpsite of Ahmadu Bello University, Zaria, Kaduna state, Nigeria in order to study the groundwater contamination pathway. Vertical Electrical Sounding (VES) using Schlumberger array was carried out at fourteen (14) stations. Ohmega terrameter was used for data acquisition. The field data obtained has been analyzed using Computer Software (ipi2win)which gives an automatic interpretation of apparent resistivity. The VES result revealed the heterogeneous nature of the subsurface geologic sequence. The geologic sequence beneath the study area is composed of topsoil (sandy-clay and sandy-lateritic), weathered basement, fracture basement layer and fresh basement. The resistivity values of the layers ranges from $8.2 \Omega \mathrm{m}$ to $\mathbf{2 8 8 4 \Omega m}$. The extremely low resistivity variation in the weathered basement identify the present of contamination plume zones in the layer. However, fracture basement and fresh basement underlying the weathered basement show lateral variation in the basement resistivity. The result shows that the contamination plume zone has tendency to contaminate the ground water.

Keywords: Contamination, Fracture basement, Fresh basement, Geoelectric, Groundwater, Leachate, Weathered and Vertical Electric Sounding (VES).
\end{abstract}

\section{INTRODUCTION}

The important of groundwater as a valuable source of portable water cannot be over emphasized. Groundwater forms the most important natural resources of any region and compliments surface sources in the provision of portable water for domestic and industrial applications. The populace is also dependent on the abundances, fertility and integrity of the soil for agriculture and other economic and industrial activities (Jatau and Ajodo, 2006). The qualities of these natural resources have been impaired by the indiscriminate location of dumpsites without regards to the health of people and damage to the environment. Waste, which are described as materials that result from an activity or process but have no immediate economic value or demand have been managed in a way that contaminates water and the environment (Asuerumen et al., 2014). In this area, wastes are generated in form of liquid decomposed at the waste site of Kubanni River as leachate which has higher conductivity due to the presence of dissolved salts (Bhuiya et al., 2002). Leachate is generally associated with high ion concentrations and hence results in very low resistivity of the rock formations containing them (Aboh, 2017). This makes geoelectrical techniques most adequate for mapping the extend of leachate contamination around dumpsites (Cristina et al., 2012). Consequently, the electrical resistivity of leachate is often very much lower than natural groundwater (Aboh, 2017). It is this contaminatedliquid that forms a plume that move outward and downward into the surrounding and underlying aquifers (Carpenter et al., 2012). These plumes may contain carcinogens such as heavy metals and less harmful ions of sodium, calcium, iron, chloride e. t. c. High concentration of these enhance it electrical conductivity. Geoelectrical method has been found very suitable for this kind of environmental study. So, when a plume enters the aquifer, it results in a large contrast in electrical properties and this method will identify these zones as an anomaly which enables the plumes to be detected (Asuerumenet al., 2014).

Location of the Study Area

Kabanni River basin occupies the Centre of southeastern sector of Zaria sheet No. 102 south-west of the 1:500000 sheet series of Nigeria ordinate survey map. It is approximately bounded by latitude $11^{\circ} 10^{\prime} 12^{\prime \prime} \mathrm{N}$ and $11^{\circ} 10^{\prime} 46^{\prime \prime} \mathrm{N}$ and longitude $07^{\circ} 36^{\prime} 55^{\prime \prime} \mathrm{E}$ and $07^{\circ} 44^{\prime} 12^{\prime \prime} \mathrm{E}$.

However, the investigation area is located at the waste site of the river (Fig. 1) which has latitude of $11^{\circ} 18^{\prime} 18.9^{\prime \prime} \mathrm{N}$ and $11^{\circ} 08^{\prime} 46^{\prime \prime} \mathrm{N}$ and longitude $07^{\circ} 36^{\prime} 55^{\prime \prime} \mathrm{E}$ and $07^{\circ} 44^{\prime} 12^{\prime \prime} \mathrm{E}$.

\section{Geology of the Area}

The study area Ahmadu Bello University main campus in Zaria, which is about $15.5 \mathrm{~km}$ from the well-known Zaria City, is approximately bounded by longitude $7^{0} 38^{\prime} \mathrm{E}$ and $7^{0} 39^{\prime} \mathrm{E}$ and latitude $11^{\circ} 09^{\prime} \mathrm{N}$ and $11^{\circ} 10^{\prime} \mathrm{N}$ Nigeria lies in pan-African mobile belt which has been affected by pan-African events through the ages of orogenic, epirogenesis, tectonic and metamorphic cycles (Oyawoye, 1964). 
Bajopas Volume 10 Number 2 December, 2017

The study area is part of the Nigeria basement complex underlain by crystalline rocks. The geological investigation of the study area reveals that the area is underlain by rock of the Older Granite that forms part of the Zaria granitic Batholith (Ike, 1998). Although there is no outcrop exposure of the granite in the study area, lateritic soil derived from its weathering is well exposed around the northeastern part of the study area.

This lateritic soil measures about $3 \mathrm{~m}$ in thickness and varies from a more hardened and less compacted layer at the top to a less hardened and more compacted layer. Dominant structural trends in the granitic Batholith of Zaria are almost in the N-S direction, conforming to the Pan-African Orogeny structural trend (Ike,1998).The study area is also characterized by a topography that is gently sloping from its northern part towards the southern part.A thick overburden covers the area with varying thickness. Underlying the overburden are crystalline rocks consisting of biotite horn blende granite. The granites belong to the older granite suite of the northwestern Nigeria, emplaced during the pan-African orogeny (McCurry, 1970).

\section{MATERIALS AND METHODS}

The geophysical investigation involves the use of vertical electric sounding (VES) method.The largest Current electrode spacing $A B$ used was $200 \mathrm{~m}$, that is, $1 / 2 A B=100 \mathrm{~m}$. The potential electrode separation, $M N$, was also increased intermittently in order to maintain a measurable potential difference, but it did exceed one-fifth of the half-current electrode separation, $1 / 2 A B$, as suggested by (Dobrin and Savit,1988). By measuring the electrical resistance to a direct current applied at the surface, this geophysical method can be used to locate fracture zones, faults and other preferred groundwater/contaminant pathways; locate clay, sand channels and locate perched water zones and depth to the bedrock (Sultan, 2012). Fourteen (14) vertical electric sounding (VES) locations were occupied within the two length of the rectangular pond (Fig. 1) containing the plumes utilizing the schlumberger electrode configuration. The VES data were interpreted using the ipi2win software. The principal instrument used for this survey is the omega terrameter. The resistance readings are displaced on the digital readout screen and then written down on the field report book.

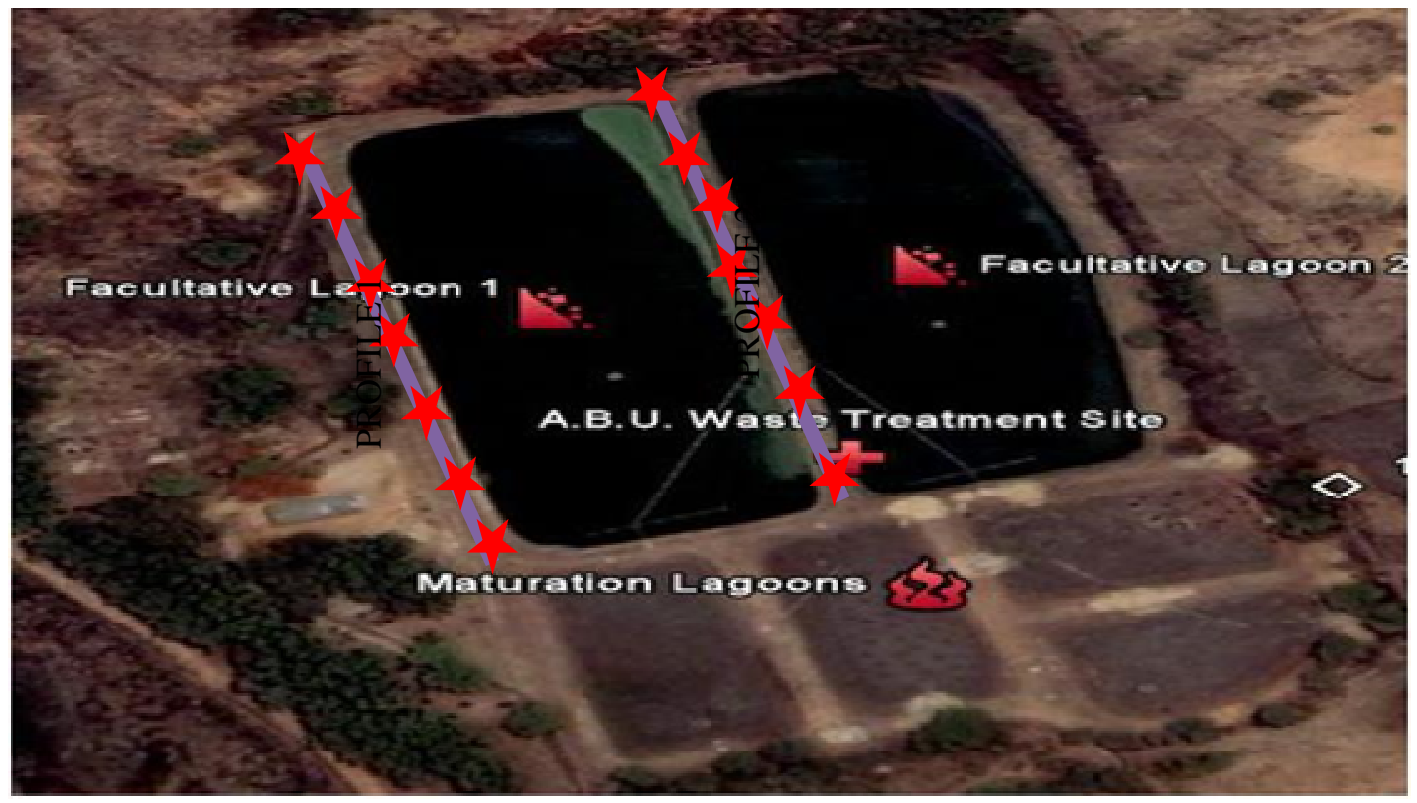

Figure 1: Location of the study area (Ahmed et al., 2012)

GENERAL PRINCIPLE OF RESISTIVITY METHOD The resistivity method is based on measuring the potentials between one electrode pair while transmitting direct current (DC) between another electrode pair. Resistivity measurements separate the subsurface into different layers base on their resistivity values (Ekweet al., 2010). The depth of penetration is proportional to the separation between the electrodes, in homogeneous ground, and varying the electrode separation provides information about the stratification of the ground.

Fig. 2 shows the current and potential difference distribution within a homogeneous isotropic ground in a vertical plane through the current electrodes $\mathrm{C} 1$ and $\mathrm{C} 2$ and potential electrode $\mathrm{P}_{1}$ and $\mathrm{P}_{2}$. When an external voltage is applied across them, there will be a flow of current through the earth from one electrode $\mathrm{C} 1$ to the other, $\mathrm{C} 2$. The resistivity method is based on measuring the potential between one electrode pair (P1 and P2, called potential electrodes) while transmitting DC between another electrode pair (C1 and C2) and $r_{1}, r_{2}, r_{3}$ and $r_{4}$ are the electrode separations. The rheostat varies the current I which is measured by the ammeter $(A)$ while the voltmeter $(V)$ measures the potential difference $\Delta \mathrm{U}$. 


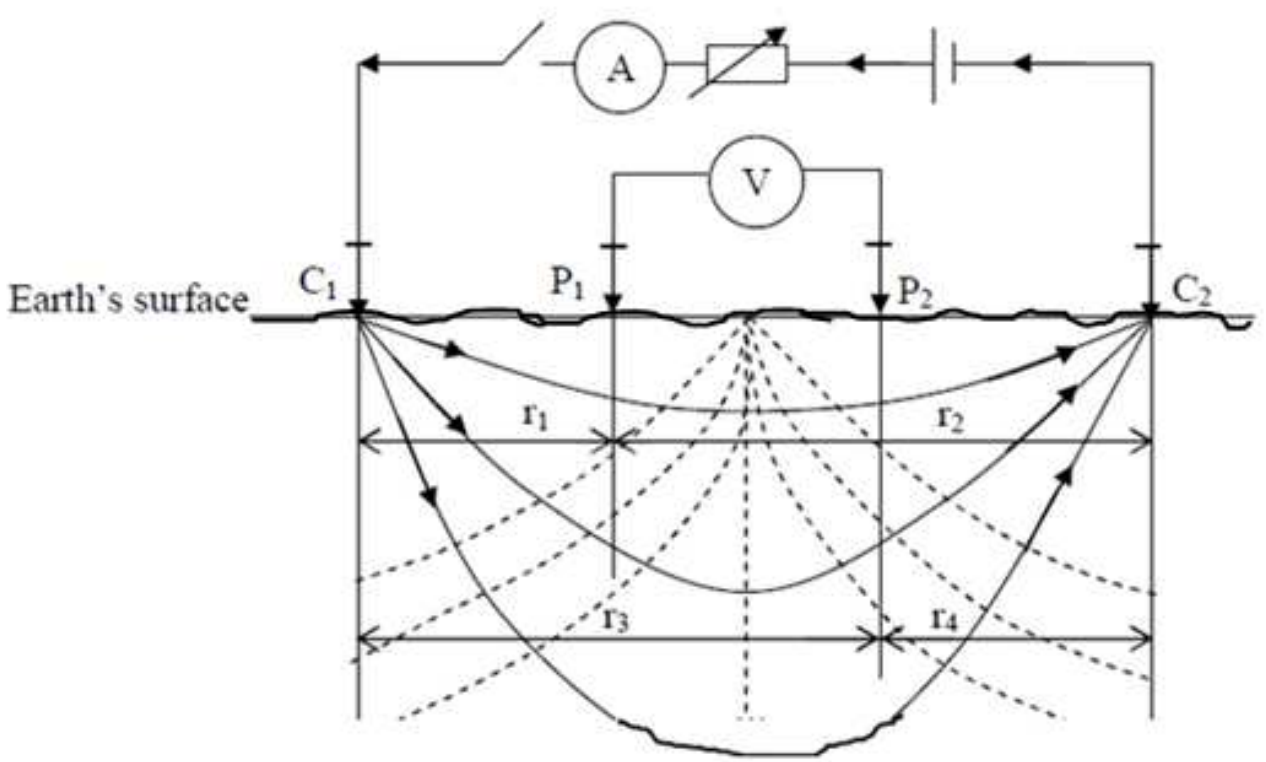

Figure 2: Current and Potential Distributions within Homogeneous Isotropic ground.

\section{THEORY OF THE RESISTIVITY METHOD}

Schlumberger array was used for the survey. $C_{1}$ and $C_{2}$ are point current electrodes through which current was driven into the ground while $\mathrm{P}_{1}$ and $\mathrm{P}_{2}$ are two potential electrodes to record the potential distribution in the subsurface within the two current electrodes (Fig. 2). From Ohm's law, the current I and electric potential $\mathrm{U}$ in a metal conductor at constant temperature is related as follows:

$\mathrm{U}=\mathrm{IR}$

where $\mathrm{R}$ is the constant of proportionality termed resistance and it is measured in ohms. The resistance $\mathrm{R}$, of a conductor is related to its length $L$ and cross sectional area $A$ by;

$\mathrm{R}=\rho L / A \quad(2.2)$

Where $\rho$ is the resistivity and it is a property of the material considered. From equations (2.1) and (2.2),

$$
\mathrm{U}=I \rho L / A \quad(2.3)
$$

The principle underlying the resistivity method is embodied in Ohm's law, which states that the current density at a given point is proportional to the electric field intensity at that point. Thus, Ohm's law gives the relationship between current density $\mathrm{J}$ (amperes $/ \mathrm{m}^{2}$ ) and electric field intensity $\mathrm{E}$ (volts/m) as:

Where $\sigma$ is the conductivity of the medium. Also $E$ is the gradient of a scalar potential $U$ (volts), i.e.,

Putting equation (2.5) into equation (2.4)

From divergence condition,

$$
J=-\sigma \nabla U
$$

Thus, from equation (2.6)

$$
\nabla . J=0
$$

Or

$$
\nabla . J=-\nabla \cdot(\sigma \nabla U)
$$

$$
\nabla \sigma \cdot \nabla U+\sigma \nabla^{2} U=0
$$

For a homogeneous earth, $\sigma$ is a constant and since the derivative of a constant is equal to zero, then the first term in equation (2.9) vanishes hence,

$$
\nabla^{2} U=0
$$

\section{VERTICAL ELECTRICAL SOUNDING (VES)}

This is also known as electrical drilling or expanding probe. It is used mainly in the study of horizontal or near horizontal interfaces. In this method the current and potential electrodes are maintained at the same relative spacing and the whole spread is progressively expanded about a fixed central point. Consequently, readings are taken as the current reaches progressively greater depth.
The measured apparent resistivity values are normally plotted against electrode spacing values on a log-log graph paper. To interpret the data from such a survey, it is normally assumed that the subsurface consists of horizontal layers. In this case, the subsurface resistivity changes only with depth, but does not change in the horizontal direction. 
In many engineering and environmental studies, the subsurface geology is very complex where the resistivity can change rapidly over short distances. The resistivity sounding method might not be sufficiently accurate for such situations. However, the technique is extensively used in geotechnical surveys to determine overburden thickness and also in hydrogeology to define horizontal zones of porous strata.

\section{RESULTS AND DISCUSSION}

For better understanding, the results of investigation are usually presented in the form of geoelectrical cross-sections. However, the topsoil and the weathered basement are regarded as the overburden while the bedrock consists of the fracture and the fresh basement rocks (Oladapo, 2013).

The modeling of VES measurement carried out at fourteen (14) stations has been used to derive the geoelectric sections for the profiles in (Fig. 2 and Fig. 3 ). These have revealed that there are mostly four and three geologic layers beneath each VES point. The geologic sequence beneath the study area is composed of topsoil, weathered basement, fracture basement and fresh basement. The topsoil composed of sandy-clayed and sandy-latritic layer with resistivity values ranging from $63.6 \Omega \mathrm{m}-773 \Omega \mathrm{m}$ and thickness varying from $1.11 \mathrm{~m}$ to $3.74 \mathrm{~m}$. It is however, observed from the geoelectric section that VES 2, 8 and 9 are characterized with resistivity value of $63.6 \Omega \mathrm{m}$,
$82.3 \Omega \mathrm{m}$ and $80.3 \Omega \mathrm{m}$ suggesting the clayed nature of the topsoil.

The second layer is the weathered basement with resistivity and thickness values varying between $8.2 \Omega \mathrm{m}$ to $493 \Omega \mathrm{m}$ and $1.89 \mathrm{~m}$ to $7.68 \mathrm{~m}$ respectively. It is however, observed from the geoelectric section that VES 3, 5, 6, 7, 12, 13 and 14 are characterized with extremely low resistivity of $8.2 \Omega \mathrm{m}, 30 \Omega \mathrm{m}, 14.2 \Omega \mathrm{m}$, $18.1 \Omega \mathrm{m}, 11.3 \Omega \mathrm{m}, 22.1 \Omega \mathrm{m}$ and $18.8 \Omega \mathrm{m}$ at a depth of $1.89 \mathrm{~m}$ to $7.68 \mathrm{~m}$. The resistivity of this layer closely agreed with Abdullahiet al., (2013). The observed regions of low resistivity in this layer suggest that the area has been heavily affected by leachate plumes contamination (Okpoli, 2013).The extremely low resistivity values in this layer suggest the contamination plume zones in these areas.

The third layer is the fracture basement with resistivity and thickness values varying from $19.3 \Omega \mathrm{m}$ to $277 \Omega \mathrm{m}$ and $6.68 \mathrm{~m}$ to $27.6 \mathrm{~m}$ respectively. It is however, observed from the geoelectric section that VES $1,2,4,6,7,8,9,10$ and 13 are characterized with low resistivity of $69.3 \Omega \mathrm{m}, 34.1 \Omega \mathrm{m}, 39.7 \Omega \mathrm{m}, 61.8 \Omega \mathrm{m}$, $57.3 \Omega \mathrm{m}, 54 \Omega \mathrm{m}, 46.3 \Omega \mathrm{m}$ and $67.3 \Omega \mathrm{m}$ at the depth of $6.68 \mathrm{~m}$ to $27.6 \mathrm{~m}$ suggesting the point of high water potential. The thickness of the VES point suggesting point for sitting borehole.

The fourth layer is presumably fresh basement whose resistivityvalue varies from $370 \Omega \mathrm{m}$ to $2884 \Omega \mathrm{m}$ with an indefinite depth.

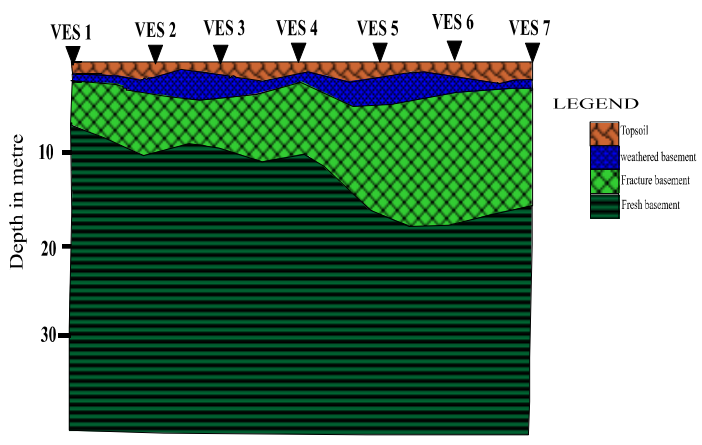

Distance in metre

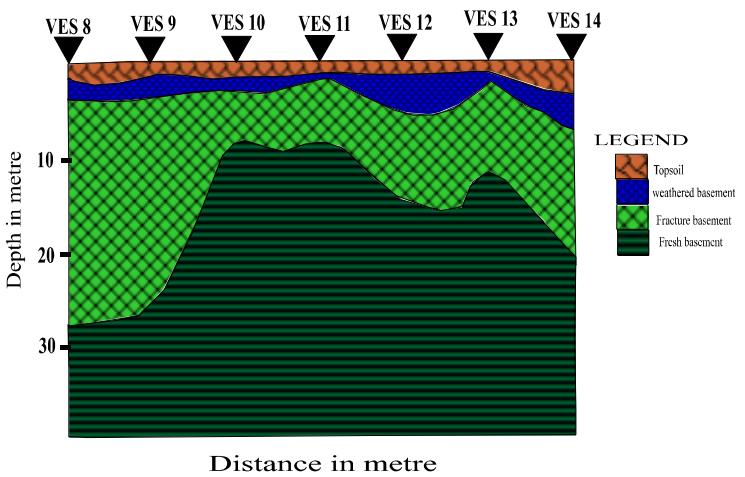

Figure 4: Profile 2

Figure 3: Profile 1

\section{CONCLUSION}

Surface geophysical investigation was used as part of the hydro geologic assessment of soil and groundwater in premises of active dumpsite located at kubanni dam of Ahmadu Bello University Zaria, Nigeria.

The resulting resistivities clearly show the existence of contamination plume zones found within the weathered basement of the overburden layer.The extremely low resistivity variation in the weathered basement identify the present of contamination plume zones in the layer. However, fracture basement and

fresh basement underlying the weathered basement show lateral variation in the basement resistivity. The result shows that the contamination plume zone has tendency to contaminate the groundwater within the region.

\section{Recommendation}

It is recommended that Induced polarization and electromagnetic method should be carried out to compliment the result. Also the lagoons should be lined at the base with impermeable materials to prevent the draining of the sewage effluent through the fracture zone. 


\section{REFERENCES}

Abdullahi, N. K., Osazuwa, I. B., Sule, P. O. and Onugba, A. (2013).Geophysical Assessment of an Active Open Dumpsite in Basement Complex of Northwestern Nigeria. International Journal of Engineering Science Invention: 2319-6734.

Aboh, H. O. (2017). Delimitation of Extend of Leachate Contamination in Dumpsite at Gonin Gora Area of Chikun LGA, Kaduna State. KADA Journal of Physics. Vol. 1, pp 114.

Ahmed, I.I., Osazuwa, I.B. and Lawal, K. M. (2012). 2D Seismic Refraction Tomography Investigation of a sewage Treatment Site. Journal of Environmental and earth Science.Vol. 2, No. 10.

Asuerimen, M., Ahmed, A. L. and Lawal, K. M. (2012): Two Dimensional Resistivity Investigation of Solid waste dumpsite at Gonin-Gora, Kaduna State. Unpublished MSc. Thesis: Department of Physics, Ahmadu Bello University, Zaria.

Bhuiya, M. A. H., Huq, N. E. and Hossain, M. M. (2002). Unplanned waste disposal land its possible impacts on subsurface environment of Dhaka City, Bangladesh environment. Vol. 2, pp 7231-7331.

Carpenter, P. J., Ding, A. and Cheng, L. (2012): Identifying Groundwater Contamination using Resistivity Survey at landfill near Maoming, China. Nature Education Knowledge, 3(7):20.

Cristina, P., Cristina, D., Alicia, F. and Pamela, B. (2012). Application of Geophysical Methods to Waste Disposal Studies, Municipal and Industrial Waste Disposal. Dr Xian-Ying Yu (Ed).

Dobrin, M.B. and Savit, C.H.(1988). Introduction to Geophysical Prospecting. Fourth Edition. McGraw- Hill Books: New York, NY.

Ekwe, A.C., Nnodu, I. N., Ugwumbah, K. I. and Onwuk, O.S. (2010). Estimation of Aquifer Hydraulic characteristics of low permeability formation from Geosounding data: A case study of oduma Town, Enugu State Nigeria. Medwell Journals, vol. 4, pp. 19-26.Doi: 10.3923/ojeci.2010.19.26

Ike, E. C. (1988), Late-stage Geological Phenomena in the Zaria Basement Granites, In Precambrian Geology ofNigeria, Geological Survey of Nigeria Spec. Pub. pp. 83-89.

Jatau, B. S. and Ajodo, R. O. (2006): Preliminary Geoenvironment evaluation of part of Kaduna north metropolis, Kaduna. A paper presented at Nigeria Association of Hydro geologists (NAH) $18^{\text {th }}$ Annual National Conference Asaba, P. 1-2.

McCurry, P. (1970): "The Geology of Zaria Sheet 21". Unpublished M.Sc. Thesis. Department of Geology, Ahmadu Bello University, Zaria.

Okpoli, C. C. (2013). Application of 2D Electrical Resistivity Tomography in Landfill Site: A Case Study of Iku, Ikare Akoko, Southwestern Nigeria. Journal of Geological Research. ID 895160

Oladapo, M. I. (2013). Hydro-geoelectric study of Ijare town Southwestern Nigeria. International Journal of water Resources and Environmental Engineering, vol. 5, pp. 687696. Doi: 10.5897/IJWREE2013.0424.

Oyawoye, P.O. (1964): "Geology of Nigerian Basement Complex". Journal of Mining and Geology. 1:110-121.

Sultan, A. S. A., (2012): Groundwater Management by Using Hydro- Geophysical Investigation: Case Study: An Area Located at North Abu Zabal City, Hydrogeology - A Global Perspective, Dr. Gholam A. Kazemi (Ed.), ISBN: 978-95351 0048-5, In Tech, Available from:http://www.intechopen.com/books/hyd rogeology a globalperspective/groundwater-management-byusing-hydro-geophysical- investigation-casestudy-an-area 